\title{
Archiconiocompsa prisca Enderlein (Neuroptera: Coniopterygidae): The first neuropteran fossil in Rovno amber (Ukraine)
}

\author{
Janusz Kupryjanowicz \& Vladimir N. Makarkin
}

Kupryjanowicz, J. \& Makarkin, V. N. 2008: Archiconiocompsa prisca Enderlein (Neuroptera: Coniopterygidae): The first neuropteran fossil in Rovno amber (Ukraine). - Entomol. Fennica 19: 25-31.

Archiconiocompsa prisca Enderlein, previously known from Baltic amber, is recorded in Rovno amber. A discussion of the systematic position of this monotypic genus is provided; it is tentatively assigned to Coniocompsini (Aleuropteryginae).

J. Kupryjanowicz, Institute of Biology, University of Bialystok, Swierkowa 20 B, 15-950 Bialystok, and Museum of the Earth Polish Academy of Sciences, Al. Na Skarpie 26/27,00-488Warszawa, Poland; E-mail: kuprzool@uwb.edu.pl V. N. Makarkin (corresponding author), Institute of Biology and Soil Sciences, Far Eastern Branch of the Russian Academy of Sciences, Vladivostok, 690022, Russia; E-mail:vnmakarkin@mail.ru

Received 22 March 2007, accepted 19 May 2007

\section{Introduction}

Amber and its insect inclusions from the Rovno Region of Ukraine is currently attracting much attention, and it has recently been intensively studied (e.g., Dlussky 2002, Dlussky \& Perkovsky 2002, Simutnik 2002, Kononova 2003, Perkovsky et al. 2003a,b, 2007, Putshkov \& Popov 2003, Fedotova \& Perkovsky 2004, 2005, Perkovsky \& Fedotova 2004, Polilov \& Perkovsky 2004, Gumovsky \& Perkovsky 2005, Tolkanitz et al. 2005a,b, Engel \& Perkovsky 2006a-c, Perkovsky 2006a,b, Simutnik \& Perkovsky 2006, Zhantiev 2006). Sixteen insect orders and about a hundred families have now been reported from Rovno amber (Perkovsky et al. 2003b, Engel \& Perkovsky 2006a, Perkovsky 2006a). This includes, however, no species of Neuroptera. The amber is chemically identical with Baltic amber (Kosmowska-Ceranowicz 1999), and both are considered to be roughly contemporaneous, Late
Eocene in the age (Engel \& Perkovsky 2006a, Perkovsky et al. 2007).

In this paper, we report the first neuropteran from Rovno amber, the coniopterygid species Archiconiocompsa prisca Enderlein, previously known from Baltic amber, and discuss the systematic position of the genus.

The family Coniopterygidae today is comprised of minute insects with reduced wing venation; it has relatively few species, distributed world wide. Despite this, they are comparatively well studied, largely stimulated by the authoritative monograph of Meinander (1972). Six species of the family have been described from Baltic amber (see list in Engel 2004), belonging to five genera, three of which are extinct: Archiconiocompsa Enderlein, 1910, Archiconis Enderlein, 1930, Heminiphetia Enderlein, 1930, all three are monotypic.

The presence of the Baltic amber Archiconiocompsa prisca in Rovno amber is not sur- 
prising. Species of Dolichopodidae (Diptera) and Rhinotermitidae (Isoptera) have been identified in common between Rovno and Baltic ambers (Grichanov 2000, Perkovsky et al. 2007). Further, $74 \%$ of ant species and all 6 species of Psocoptera recorded from Rovno amber were previously described from Baltic amber (Dlussky \& Perkovsky 2002, Engel \& Perkovsky $2006 \mathrm{~b}, \mathrm{c})$. Such shared species in other insect families are not yet known, but most of these are represented in Rovno amber by few species or have not yet been closely examined. The relationship between the Baltic and Rovno amber insect faunas is therefore only beginning to be evident as the Rovno assemblage becomes better known. Nevertheless, it is currently apparent that the Rovno amber insect assemblage is distinct from that of Baltic amber by differing relative abundances of orders, families and groups within families (Perkovsky et al. 2003a,b, Engel \& Perkovsky 2006a, Perkovsky et al. 2007).

\section{Material and methods}

The material examined comes from the Klesov locality, about $90 \mathrm{~km} \mathrm{NNE}$ of Rovno in the Rovno Region, Ukraine. The specimen was donated to the Museum of the Earth by Andrzej Wiszniewski (A.Wiszniewski collection), and prepared for this study by Janusz Kupryjanowicz. It is embedded in a translucent lump of amber with measurements $14 \times 12 \times 5 \mathrm{~mm}$. There are no syninclusions. Photographs and measurements were done using a Zeiss SV 11 microscope.

Terminology mainly follows Meinander (1972). Abbreviations used in the text and figures are: A1, A2, 1st and 2nd anal veins (A); Cul, $\mathrm{Cu} 2$, anterior and posterior branches of the cubital vein $(\mathrm{Cu}) ; \mathrm{M} 1+2, \mathrm{M} 3+4$, branches of the medial vein $(\mathrm{M}) ; \mathrm{R} 1$, anterior branch of the radial vein (R); R2+3, R3+4, branches of the radial sector (Rs); Sc1, Sc2, anterior and posterior branches of the subcostal vein (Sc). Crossveins are designated after the longitudinal veins which they connect, and numbered in sequence from the wing base (if more than one crossvein between a vein pair is present), e.g., 2m-cul, distal crossvein connecting $\mathrm{M}$ and $\mathrm{Cul}$.

Institutional abbreviations: GZG, Geowis- senschaftliches Zentrum der Universität Göttingen $[=$ Geoscience Centre of the University of Göttingen], Germamy; MZ, Muzeum Ziemi Polskiej Akademii Nauk [=Museum of the Earth of the Polish Academy of Sciences], Warsaw, Poland.

\section{Systematic paleontology}

\subsection{Archiconiocompsa prisca Enderlein, 1910 (Figs 1-4)}

Archiconiocompsa prisca Enderlein, 1910: 676, figs 1-4 (original description); Enderlein 1930: 101 (keyed); Meinander 1972: 34 (systematic position); Meinander 1975: 53 (taxonomic remarks); Meinander 1979: 20, 23 (systematic position, biogeography); Keilbach 1982: 284 (listed); Nel 1990: 343 (listed); Spahr 1992: 71 (listed); Weitschat \& Wichard 1998: 146, pl. 53, figs c, e (photographs of two additional specimens); Dobosz \& Krzemiński 2000: 220 (listed); Engel 2004: 134 (listed, systematic position).

Holotype (female): Number unknown, earlier deposited "in the collection of Professor Dr. R. Klebs" in Königsberg [=Kaliningrad], now lost or possibly destroyed, not found in the part of his collection preserved in the GZG (Ch. Neumann, M. Reich, pers. comm.). Baltic amber (precise locality collected unknown). Late Eocene.

Additional material (apparently females): (1) No. 5907, deposited in the SZG, labelled "Phys. Oek. Ges. [=Physikalisch-Ökonomischen Gesellschaft, Königsberg]/ Nr. 9267./ II.1. Nr. 4.”; “5907/ Coniopterix [sic]/ 5278". Baltic amber (precise locality collected unknown); (2) No. MZ 24667, deposited in the MZ. Ukraine: Rovno [=Rivne] Region: Klesov [=Klesiv] locality [51.315N 26.907E] (Rovno amber). Late Eocene.

Description. (Rovno specimen): Body, appendages fuscous. Head with very large eyes (Fig. 2a); vertex not especially prominent, covered with rather scarce, fine hairs. Antennae short, 16-segmented; scape, pedicel size similar, length ca. 1.5 times width, stouter than other segments; 1st segment of flagellum (3rd antennal segment) longer than other flagellar segments, length ca. 2.2 times width; flagellar segments increasingly 


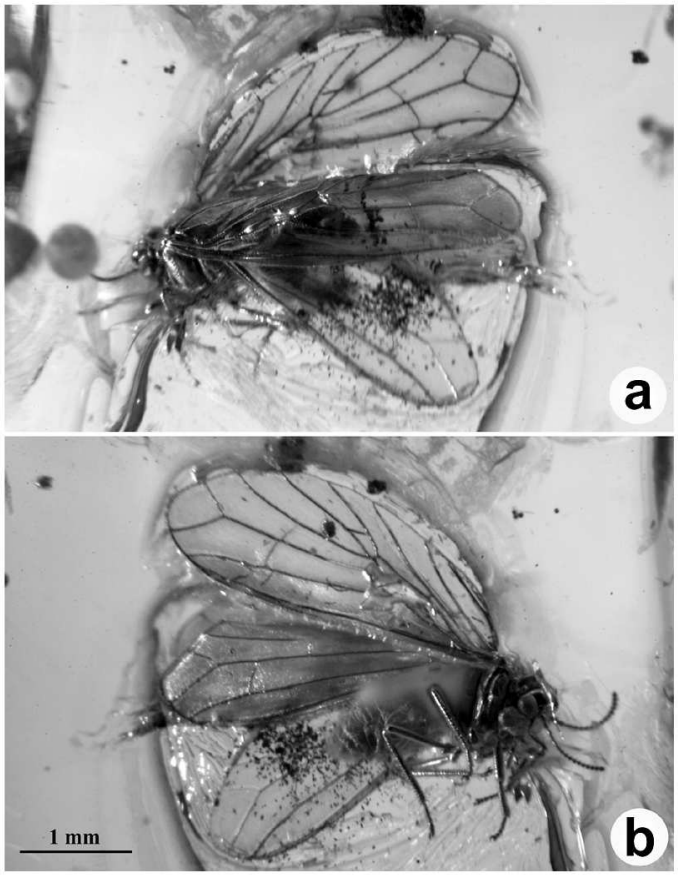

Fig. 1. Archiconiocompsa prisca, Rovno amber specimen MZ 24667. - a. Left lateral view. - b. Right lateral view.

shorter, wider toward apex; terminal flagellomere tapering. Antennae covered with moderately long, dense hairs. Terminal segment of maxillary palps much longer, broader than others. Structures of thorax poorly visible by preservation, but as evident appear normal for family (Fig. 3b). Legs of usual morphology for family, slender; femur of fore leg stouter than other leg segments. Femur, tibia of fore leg much shorter than those of mid, hind legs. All femora covered with short, sparse setae; tibiae with longer, denser setae. Tarsi five-segmented, all basitarsi longest of tarsomeres, as long as, or slightly longer than four other tarsomeres together. Abdomen covered (at most) with microtrichia. Abdominal plicaturae on third to sixth sternites, most prominent on fifth sternite (Fig. 2b). Seventh segment relatively long, eighth segment appearing very short (indistinct preservation). Genital structures suggests specimen female, but not clearly visible by cloudy amber.

Forewing (Fig. 3). Length $3.3 \mathrm{~mm}$, maximum width $1.2 \mathrm{~mm}$. Sc parallel to costal margin. Two basal crossveins (=subcostal veinlets) in costal space: weaker basad, rather strong distad oppo-

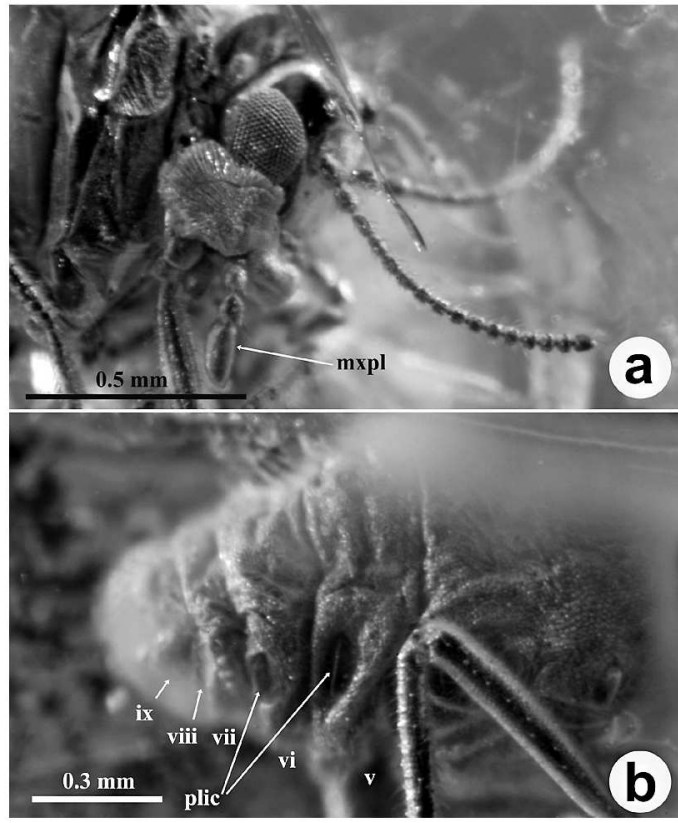

Fig. 2. Archiconiocompsa prisca, Rovno amber specimen MZ 24667. - a., Head. - b. Abdomen (lateral view). mxpl, maxillary palpus; plic, plicaturae; $v$ to ix, 5th to 9th sternites.

site basal sc-r. Crossvein-like part of Sc2 meeting $\mathrm{R} 1$ distad r1-rs. Basal sc-r very short. Sc2 slightly curved toward $\mathrm{Sc1}$, but apically separate. Origin of Rs at proximal 1/3th of wing length. Rs basally sinuous with distinct knee (bend, as in Meinander 1972) at 1rs-m; division into R2+3, R4+5 shifted distally, r1-rs joining Rs strongly proximad this fork. $\mathrm{R} 2+3, \mathrm{R} 4+5$ rather short, broadly spaced, angle between them almost 90 degrees. 1rs-m at knee of Rs not detected, but crossvein-like weak structure visible slightly distad fork of M; 2rs-m long, nearly opposite $\mathrm{r} 1-\mathrm{rs}$. $\mathrm{M}$ coalescent with $\mathrm{R}$ for short distance or connecting with it by very short crossvein proximally (this portion not clearly visible; possibly former variant in left wing, latter in right), deeply bifurcate distally, with branches very long, relatively closely spaced; long setae on two large thickenings of $\mathrm{M}$. $1 \mathrm{~m}$-cul very short, connecting $\mathrm{M}, \mathrm{Cu} 1$ slightly distal to fork of $\mathrm{Cu} ; 2 \mathrm{~m}$-cul very strong, short, slightly proximad fork of $\mathrm{M}$. $\mathrm{Cu}$ dividing into $\mathrm{Cu} 1, \mathrm{Cu} 2$ close to wing base; cu1-cu2 short, strongly proximad $2 \mathrm{~m}$-cul. Two long crossveins between $\mathrm{Cu} 1, \mathrm{~A} 1$; 1cu1-al strongly curved. No crossvein between A1, A2. Proximal half of A2, 


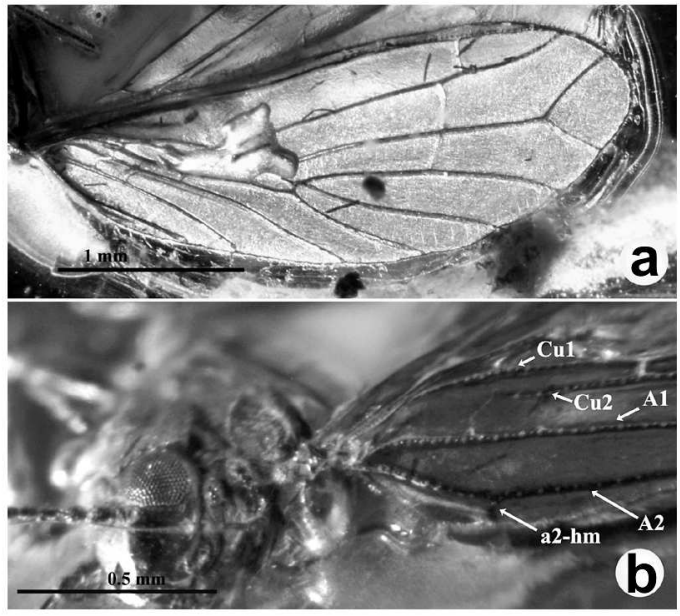

Fig. 3. Archiconiocompsa prisca, Rovno amber specimen MZ 24667. - a., Right forewing. - b. Thorax (dorsal view) and anal area of right forewing. a2-hm, crossvein between A2 and hind margin.

hind margin connected by rather short crossvein nearly perpendicular to A2 (Fig. 3b). All longitudinal veins with one row of short dense setae, prominent particularly on Sc1, Sc2. Marginal fringes short. Membrane hyaline, slightly fuscous, without distinct colour patterning.

Hindwing. Length ca. $2.5 \mathrm{~mm}$. Sc2 slightly curved toward $\mathrm{Sc} 1$, but not joined. Crossvein-like part of Sc2 joins R1 much distad r1-rs. Configuration of Rs fork as in forewing. 2rs-m nearly at wing mid-point. Stem of M, M3+4 form straight line; $\mathrm{M} 1+2$ originates at very obtuse angle to $\mathrm{M}$; $\mathrm{M} 1+2, \mathrm{M} 3+4$ parallel. Other portions of hindwings obscured by forewings, venation not visible.

Remarks. Although the Baltic amber specimen GZG 5907 was formerly deposited in Königsberg (judging by its label), it does not appear to be the holotype of Archiconiocompsa prisca. Based on the original description of the holotype of A. prisca, the size of specimen GZG 5907 is much greater than that of the holotype and it differs in venational details. The holotype of $A$. prisca was described with enough detail by Enderlein (1910) to confidently identify the Rovno specimen as conspecific, based on almost complete morphological agreement between them, particularly in fine details of venation, the antennae and the abdomen. However, there are some minor differences, which we presume to be either intraspecific variation, possible errors in the original description, or different interpretations of the features. These include the following four differences. [1] The most distinct difference in venation is the position of the crossvein-like part of $\mathrm{Sc} 2$, which is situated opposite to the radial crossvein in the holotype, and distad that crossvein in the Rovno specimen (Fig. 3a). We interpret this as intraspecific variation. Similar variations occur within a species in the closest extant genus Coniocompsa, for example in C. silvestriana Enderlein $[=C$. smithersi Meinander] (see Meinander 1972: figs 51A and 51G) widely distributed in Africa. Moreover, the position of the crossvein-like part of $\mathrm{Sc} 2$ in the specimen 5907 is identical to that found in the Rovno specimen. [2] The Rovno specimen is larger than the Baltic amber holotype: the holotype forewing is $2.4 \mathrm{~mm}$ long, the Rovno specimen $3.3 \mathrm{~mm}$. Although such size difference seems great, it is not exceptional within the Coniopterygidae. Moreover, specimen 5907 is even larger than the Rovno specimen: the forewing of the former is ca. $3.7 \mathrm{~mm}$ long. [3] According to Enderlein (1910), plicaturae are present on the second to fifth sternites. But we guess that they actually occur on the third to the sixth sternites, based on the observation that between most distal segment bearing plicaturae (fifth of Enderlein, sixth in our interpretation) and genital segments (ninth-tenth) in the Rovno specimen there are two segments: one relatively large (seventh) and one small (eighth) (Fig. 2b). Moreover, the plicaturae on the second abdominal segment in genera of Aleuropterygini and Coniocompsini (to which this genus most closely related) are usually absent, or there are at most only traces of them present (Meinander 1972). [3] Enderlein (1910) stated that the third antennal segment is almost three times as long as wide, and is the narrowest of any segment. This segment in the Rovno specimen appears to be not particularly more slender than the next distal and only ca. 2.5 times longer than wide (Fig. 2a). [4] Enderlein (1910: fig. 1) showed in the forewing A2 connected with the hind margin by a long oblique crossvein, so that it appears bifurcated. In Rovno specimen, this crossvein is not so long, and it is nearly perpendicular to A2. Unfortunately, it is impossible to check the accuracy of Enderlein's drawing because of loss of the type; it 
Fig. 4. Archiconiocompsa prisca, Rovno amber specimen $\mathrm{MZ}$ 24667. Right forewing venation (thickenings on Media drawn from left forewing).

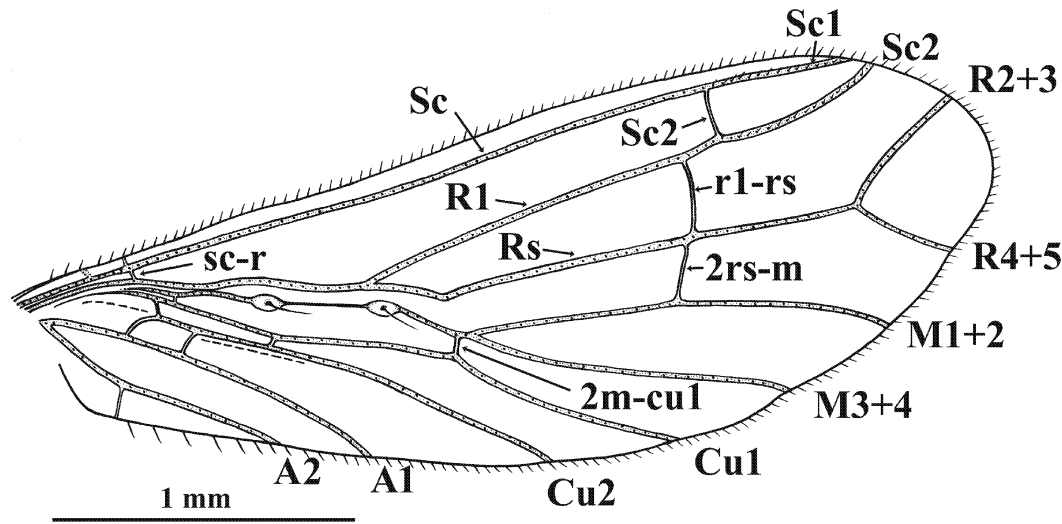

is possible that the anal area was slightly incurved (as in Rovno specimen, see Fig. 3a), and Enderlein's drawing (1910: fig. 1) is actually a reconstruction of the venation, perhaps partially incorrect.

\subsection{Systematic position of the genus Archiconiocompsa}

The forewing venation of the genus Archiconiocompsa is most similar to that of the extant genus Coniocompsa Enderlein, 1905. The latter is distributed in the tropical regions of Africa and Asia, and in the Hawaii islands (Meinander 1979; Sziráki 1998). The phylogenetic relationship of Archiconiocompsa and Coniocompsa is not entirely clear, although their forewing venations are quite distant from other genera, i.e., they share some venational states not present in other conipterygids. These include: (a) the similar configuration of the fork of Rs (R2+3 and R4+5 are rather short, broadly spaced); (b) very large thickenings on M; (c) Rs basally sinuous, with a distinct knee at 1rs-m, so that the proximal portion of $\mathrm{Rs}$ and $\mathrm{M}$ are close to each other; (d) Sc2 is curved apically toward Sc1. Character states (b)(d) may be identified as apomorphic at the family/ subfamily levels. The plesiomorphic conditions of these characters occurring in the vast majority of coniopterygids (or aleuropterygines including fossil) are: thickenings on $\mathrm{M}$ are absent or small; Rs is smooth, without a knee at 1rs-m, and Sc2 is not curved toward Sc1. The peculiar configuration of the fork of Rs might be identified as a putative synapomorphy of Archiconiocompsa +
Coniocompsa, but a sister-group relationship of these genera is only suggestive (see below).

The male genitalia of Archiconiocompsa are unknown, but it seems to be a valid genus, judging by the venation. It differs from Coniocompsa in particular by (1) $\mathrm{M}$ in forewing is deeply forked in both wings [in Coniocompsa this vein is always simple, except $C$. furcata Banks, in which $M$ is shallowly forked (see Meinander 1972: fig. 46B)]; (2) $\mathrm{Cu}$ in forewing is forked near the wing base $[\mathrm{Cu}$ is forked much distal in Coniocompsa]; (3) two crossvein between $\mathrm{Cu}$ and $\mathrm{Al}$ in the forewing, joining $\mathrm{Cu} 1$ [one crossvein, joining the stem of $\mathrm{Cu}$ in Coniocompsa]; (4) a crossvein is present between $\mathrm{Sc}$ and $\mathrm{R}$ in the forewing [absent in Coniocompsa]; (5) $\mathrm{Sc} 2$ in hindwing is not joined apically with $\mathrm{Sc1}$ [joined in Coniocompsa]; (6) crossvein is present in the hindwing between $\mathrm{Cu} 1$ and $\mathrm{Cu} 2,(7)$ and between $\mathrm{A} 1$ and A2 [both absent in Coniocompsa]. In general, the venation of coniopterygids is strongly reduced compared with that of other neuropteran families. Therefore, the character states (1)-(7) found in Archiconiocompsa, which represent the more complete/ unspecialized venation relative to Coniocompsa are interpreted as plesiomorphies within the generic group (if Archiconiocompsa belongs to the Coniocompsini, see below) or within the subfamily/ family.

Based on the presence of abdominal plicaturae, Coniocompsa and Archiconiocompsa belong together in the subfamily Aleuropteryginae with confidence. There are three tribes recognized in the Aleuropteryginae: Aleuropterygini Enderlein, 1905, Coniocompsini Enderlein, 1905 and Fontenelleini Carpentier \& Lestage, 1928 
(the latter is possibly paraphyletic: Engel 2004). The vast majority of fossil Aleuropteryginae belong to Fontenelleini, including 12 species (Engel 2004, Nel et al. 2005). Exceptions are Archiconiocompsa and the poorly known Juraconiopte$r y x$ Meinander, which was tentatively assigned to this subfamily (Engel 2004). Archiconiocompsa surely does not belong to Fontenelleini, as its hindwing crossvein rl-rs joining Rs strongly proximad the fork of Rs is distinctive. This genus was originally assigned to the tribe Aleuropterygini (Enderlein 1910). Later, it was considered as having "an intermediate position between Aleuropterygini and Coniocompsini" (Meinander 1972: 34), and subsequently was referred to Coniocompsini (Meinander 1979). Engel (2004) stated the opinion that this genus has an uncertain tribe level position within the Aleuropteryginae. If our interpretation of the plicaturae position on abdominal segments (third to sixth) is correct, then the probability of assignment of this genus to Aleuropterygini is increased, because plicaturae are unknown to occur on the sixth segment in Coniocompsini. The structures of the female abdominal apex in the Rovno specimen appear most similar to those of species of Coniocompsa (see for example Meinander 1972: figs 45C, 46F, $51 \mathrm{C}$ ), and therefore would associate it with the Coniocompsini. Venational characters are contradictory, allowing assignment to either taxon. As Meinander (1972) correctly mentioned, the hindwing venation is more similar to that of Aleuropterygini than of Coniocompsini. Archiconiocompsa shares with Aleuropterygini all four forewing venational states by which Archiconiocompsa and Coniocompsa are distinguished (above). These states, however, are plesiomorphic. On the other hand, the clearly apomorphic venational features shared by Archiconiocompsa and Coniocompsa (above), the 16-segmented antennae and possible genital resemblance of $\mathrm{Archi}$ coniocompsa to Coniocompsa, are suggestive of the Coniocompsini.

In summary, although an argument made by previous authors that the tribe position of Archiconiocompsa to be rather uncertain has some strengths, in some respects indeed it is intermediate between the Aleuropterygini and the Coniocompsini, still, we tentatively assigned it to the Coniocompsini, based on the presence of these apomorphic features, which we consider to be significant. If this is correct, then the Coniocompsini should include Archiconiocompsa and Coniocompsa, with the former possessesing a number of plesiomorphic character states not shared with the latter (see above).

Acknowledgements. We thank Andrzej Wiszniewski (Białystok) for donation of amber with inclusions, including that examined in this study, to the Museum of the Earth; Christian Neumann (Museum für Naturkunde, Berlin) for providing information on the holotype of Archiconiocompsa prisca; Mike Reich (Geowissenschaftliches Zentrum der Universität Göttingen) for providing us with the photographs of the Baltic amber Neuroptera deposited in the Zentrum; Evgeny E. Perkovsky (Schmalhausen Institute of Zoology, Kiev), S. Bruce Archibald (Museum of Comparative Zoology, Massachusetts); Sonja Wedmann (Institut für Paläontology, Bonn), and an anonymous reviewer for helpful discussions and comments that improved this paper; S. Bruce Archibald and John D. Oswald (Texas A\&M University) for correction of English; Galina Sinelnikova (Institute of Biology and Soil Science, Vladivostok, Russia) for help with drawing.

\section{References}

Dlussky, G. M. 2002: Ants of the genus Dolichoderus (Hymenoptera: Formicidae) from the Baltic and Rovno ambers. - Paleontol. J. 36: 50-63.

Dlussky, G. M. \& Perkovsky, E. E. 2002: Ants (Hymenoptera, Formicidae) from the Rovno amber. - Vestn. Zool. 36(5): 3-20. (In Russian, with English abstract).

Dobosz, R. \& Krzemiński, W. 2000: A new species of the Coniopterygidae (Neuroptera) from Baltic amber. Pol. Pismo Entomol. 69: 219-224.

Enderlein, G. 1910: Über de Beziehungen der fossilen Coniopterygiden zu den recenten und über Archiconiocompsa prisca nov, gen. nov. spec. - Zool. Anz. 35: 673-677.

Enderlein, G. 1930: Die Klassifikation der Coniopterygiden auf Grund der recenten und fossilen Gattungen. Arch. Klassifikat. Phylogenet. Entomol. 1(2): 98-114.

Engel, M. S. 2004: The dustywings in Cretaceous Burmese amber (Insecta: Neuroptera: Coniopterygidae). - J. Syst. Palaeontol. 2: 133-136.

Engel, M. S. \& Perkovsky, E.E. 2006a: An Eocene bee in Rovno amber, Ukraine (Hymenoptera, Megachilidae). - Am. Mus. Novit. 3506: 1-11.

Engel, M. S. \& Perkovsky, E. E. 2006b: Psocoptera (Insecta) in Eocene Rovno amber (Ukraine). - Vestn. Zool. 40: $175-179$.

Engel, M. S. \& Perkovsky, E. E. 2006c: Sphaeropsocus kuenowii Hagen in Rovno amber from the Ukraine (Psocoptera: Sphaeropsocidae). — Entomol. News 117: 243-245. 
Fedotova, Z. A. \& Perkovsky, E. E. 2004: New gall midges (Diptera, Cecidomyiidae) from the Rovno amber: subfamily Lestremiinae, tribes Strobliellini and Campylomyzini; subfamily Porricondylinae, tribes Diadocidiini and Asynaptini. — Paleontol. J. 38: 518-547.

Fedotova, Z. A., \& Perkovsky, E. E. 2005: New gall midges (Diptera, Cecidomyiidae) from the Rovno amber: subfamily Porrycondylinae (tribes Bryocryptini and Winnertziini) and subfamily Lasiopterinae (tribes Brachyneurini and Oligotrophini). - Paleontol. J. 39: 41-51.

Grichanov, I. Ya. 2000: Notes on Dolichopodidae (Diptera) from Ukrainian and Baltic amber. - Int. J. Dipter. Res. 11: 129-131.

Gumovsky A. V. \& Perkovsky E. E. 2005: Taxonomic notes on Tetracampidae (Hymenoptera: Chalcidoidea) with description of a new fossil species of Dipricocampe from Rovno amber. - Entomol. Probl. 35: $123-130$.

Keilbach, R. 1982: Bibliographie und Liste der Arten tierischer Einschlüsse in fossilen Harzen sowie ihrer Aufbewahrungsorte. Teil 1. - Dtsche. Entomol. Z. 29: 129-286.

Kononova, S. V. 2003: New species of egg-parasitizing wasps of the genus Idris (Scelionidae, Proctotrupoidea) of the Rovno amber. - Paleontol. J. 37: 275279 .

Kosmowska-Ceranowicz, B. 1999: Succinite and some other fossil resins in Poland and Europe (deposits, finds, features and differences in IRS). - Estud. Mus. Cienc. Nat. Álava 14 (núm. espec. 2): 73-117.

Meinander, M. 1972: A revision of the family Coniopterygidae (Planipennia). - Acta Zool. Fenn. 136: 1-357.

Meinander, M. 1975: Fossil Coniopterygidae (Neuroptera). — Not. Entomol. 55: 53-57.

Meinander, M. 1979: The phylogeny and geographical distribution of the Aleuropteryginae (Neuroptera, Coniopterygidae). - Ann. Entomol. Fenn. 45: 16-23.

Nel, A. 1990 [1991]. Nouveaux insectes neuropteroïdes fossiles de l'Oligocene de France (Neuroptera et Megaloptera). - Bull. Mus. Natl. Hist. Nat. (Paris). Sect. C (Sci. Terre) (4) 12: 327-349.

Nel, A., Perrichot, V. \& Azar, D. 2005: New and poorly known fossil Coniopterygidae in Cretaceous and Cenozoic ambers (Insecta: Neuroptera). - Ann. Zool. (Wars.) 55: 1-7.

Perkovsky, E. E. 2006a: Occurrence of ant (Hymenoptera, Formicidae) and aphid (Homoptera, Aphidinea) syninclusions in Saxonian and Rovno ambers. - Paleontol. J. 40: 190-192.

Perkovsky, E. E. 2006b: First occurrence of syninclusion of ants Ctenobethylus goepperti (Mayr) (Hymenoptera: Formicidae) and matsucoccids (Homoptera: Matsucoccidae) in Rovno amber. - Russ. Entomol. J. 15: 419-420.

Perkovsky, E. E. \& Fedotova, Z.A. 2004: New species of gall midges (Diptera, Cecidomyiidae) from Rovno amber: subfamily Lestremiinae, tribes Micromyiini and Peromyiini. - Paleontol. J. 38: 396-406.

Perkovsky, E. E., Zosimovich, V. Yu. \& Vlaskin, A. Yu. 2003a: Rovno amber fauna: a preliminary report. Acta Zool. Cracov. 46 (suppl. "Fossil Insects"): 423 430.

Perkovsky, E. E., Zosimovich, V. Yu. \& Vlaskin, A. Yu. 2003b: Rovno amber insects: first results of analysis. - Russ. Entomol. J. 12: 119-126.

Perkovsky, E. E., Rasnitsyn, A. P., Vlaskin, A. P. \& Taraschuk, M. V. 2007: A comparative analysis of the Baltic and Rovno amber arthropod faunas: representative samples. - Afr. Invertebr. 47: 229-245.

Polilov A. A. \& Perkovsky, E. E. 2004: New Species of Late Eocene feather-winged beetles (Coleoptera, Ptiliidae) from the Rovno and Baltic amber. - Paleontol. J. 38: 664-668.

Putshkov P. V. \& Popov Yu. A. 2003: The first find of Microphysidae from the Rovno amber (Heteroptera, Cimicomorpha). - Ann. Up. Sil. Mus. (Entomol.) 12: 81-86.

Simutnik S. A. 2002: A new genus of encyrtid wasps (Hymenoptera, Chalcidoidea, Encyrtidae) from Late Eocene Rovno amber (Ukraine). — Vestn. Zool. 36(4): 99-102. (In Russian, with English abstract).

Simutnik, S. A. \& Perkovsky, E. E. 2006: A description of the encyrtid male (Hymenoptera, Chalcidoidea, Encyrtidae) with archaic structure of metasoma from Rovno amber. - Vestn. Zool. 40: 283-286.

Spahr, U. 1992: Ergänzungen und Berichtigungen zu R.Keilbachs Bibliographie und Liste der Bernsteinfossilien - Klasse Insecta [Ausgenomen: "Apterygota", Hemipteroidea, Coleoptera, Hymenoptera, Mecopteroidea]. - Stuttg. Beitr. Natkd. Ser. B (Geol. Palaeontol.) 182: 1-102.

Sziráki, G. 1998: Zoogeographic relations of South Asian coniopterygids (Neuroptera, Coniopterygidae). Acta Zool. Fenn. 209: 249-254.

Tolkanitz, V. I., Narolsky, N. B. \& Perkovsky, E.E. 2005a: A new species of parasitic wasp of the genus Pherhombus (Hymenoptera, Ichneumonidae, Pherhombinae) from the Rovno amber. - Paleontol. J. 39: 511 513.

Tolkanitz, V.I., Narolsky, N. B. \& Perkovsky, E. E. 2005b: New data of fossil ichneumon wasp Pherhombus doli$n i$ (Hymenoptera, Ichneumonidae, Pherhombinae) from Rovno and Bitterfeld amber. - Vestn. Zool. 39(5): 78. (In Russian, with English summary).

Weitschat, W. \& Wichard, W. 1998: Atlas der Pflanzen und Tiere im Baltischen Bernstein. - Dr. Friedrich Pfeil Verlag, München. 256 pp. [English edition: 2002: Atlas of plants and animals in Baltic amber. Dr. Friedrich Pfeil Verlag, München].

Zhantiev R. D. 2006. New species of Late Eocene dermestid beetles (Coleoptera, Dermestidae) from the Rovno and Baltic ambers. Paleontol. J. 40: 560-563. 